\title{
The Congo crisis, the United Nations, and Zimbabwean nationalism, 1960-1963
}

\author{
Timothy Scarnecchia ${ }^{\star}$
}

\begin{abstract}
The United Nations (UN) peacekeeping mission in the Congo in 1960-63 is a major chapter in African and Cold War history. The political consequences of the peacekeeping mission, particularly the use of UN troops against Moise Tshombe's secessionist Katanga Province, reverberated in neighbouring African States as well. The contours of the UN's role in the Congo crisis are well known, but this article will consider how UN intervention created a framework for the conflict between white minority rule and African nationalists in Southern Rhodesia. This article suggests that the intersection of Cold War politics and Southern African racial politics helped to create a situation in Southern Rhodesia in which white politicians felt threatened by the UN's intervention, while Zimbabwean nationalists viewed cautiously the role of the UN as pan-African nationalism in the Congo became consumed by Cold War imperatives. The Katanga secession also demonstrated to both white politicians and Zimbabwean nationalists how intransigence and a small fighting force could challenge much more powerful nations in Cold War Africa.
\end{abstract}

* Timothy Scarnecchia is Associate Professor of History at Kent State University, Kent, Ohio, USA. He is the author of The urban roots of democracy and political violence in Zimbabwe: Harare and Highfield, 1940-1964 (University of Rochester Press, 2008). 


\section{Timothy Scarnecchia}

\section{Introduction}

The Congo crisis, as it took shape in 1960 and 1961, centred on the inability of the first elected Prime Minister, Patrice Lumumba, to retain control after the revolt of the army on 11 July 1960, and the mobilisation of large numbers of Belgian troops to defend Belgians in the Congo. The Katanga Province, the mineral-rich southern province dominated by Belgian mining interests, seceded on 12 July 1960 from the Congo, creating a major crisis for Lumumba. The United Nations moved swiftly in response to Lumumba's immediate request for assistance, deploying on 15 July a large multinational peacekeeping force, the United Nations Operations in the Congo (UNOC), to assist Lumumba's government contain the crisis and limit the potential for a larger conflict. In his statement to the Security Council on 8 August 1960, Secretary-General Dag Hammarskjöld clarified the purpose of UNOC to force the 'complete withdrawal of the Belgian troops' in order to protect the sovereignty of the Congo. He also argued that the UNOC mission was to guarantee that the democratic process would 'be determined solely by the people of the Congo'. Hammarskjöld linked UNOC to another goal: '.. finally, unanimity would be maintained, among Africans and non-Africans alike, here at the United Nations ...' (Cordier and Foote 1975:71). The importance of the Congo mission was therefore not only for the future of the Congo, but given the rapid growth of new African member states in the United Nations in 1960, UNOC was also a test of the impartiality of the institution.

By September 1960, the intrigues in the Congo's capital of Leopoldville had pushed Lumumba's army chief of staff, Colonel Joseph Mobutu, who was advised and funded by the American Central Intelligence Agency (CIA), to carry out a coup that expelled the Soviets and Lumumba supporters from the capital. The Soviets continued to support Lumumba, however, while the Americans and the Belgians worked to 'remove' Lumumba permanently from Congolese politics. After Lumumba's assassination in January of 1961, the United Nations, under intense criticisms from the Soviets for the handling of the Congo crisis, acted in February to strengthen UNOC's mission by authorising the use of force in order to avoid civil war and to reunite all provinces into the former Congo. The message of Security Council Resolution 161 (1961) was that Katanga would 
not be allowed to secede from the Republic and, if necessary, the UN would use force to push the Belgians out of Katanga. The Soviets, in the meantime, had been supporting Lumumba's group, now led by Antoine Gizenga in Stanleyville in eastern Congo, and the balance of power in the conflict meant that in order to prevent a war between Katanga and the forces in Stanleyville, the UN forces would have to act in Katanga. They did this in August-December 1961, and the use of force brought Katanga's leader Moise Tshombe to negotiate, although the end of Katanga's secession would not come until 15 January 1963.

The historical literature on the Congo crisis is quite large and recent works have done an excellent job of reconstructing the diplomatic relations around the crisis (Kent 2010; Namikas 2002), including the role of the Central African Federation (CAF) in supporting Katanga (Hughes 2003; Stapleton 2009). This article addresses the relationship of the Congo crisis to the Rhodesian crisis occurring at the same time but from the perspective of Southern African interests. Before examining the impact of the Congo crisis on Zimbabwean nationalists' ${ }^{1}$ view of the United Nations, it is useful to explore how CAF Prime Minister Sir Roy Welensky's support for Moise Tshombe's Katanga created a specifically Southern Rhodesian interpretation of the Congo crisis and the role of the UN there.

\section{Strange bedfellows: Tshombe and Welensky}

From the point of view of white politicians in Southern Africa, the 1961 UN military operations against the Belgians and white mercenaries (including many Rhodesians and South Africans) defending Katanga in late August and midSeptember were seen as a sacrifice of Western economic interests - control of the Katanga's mining resources - in return for Soviet support of a negotiated end to the civil war. If the UN could force Katanga back into the Central government, it was argued, the Soviets would stop their support of Antoine Gizenga's secessionist government in Stanleyville and therefore avoid 'another Korea' in central Africa. The open support of Katanga by the CAF Prime Minister Welensky and the

1 In this article the term 'Zimbabwean nationalists' represents African politicians seeking to obtain majority rule in Southern Rhodesia, and therefore is distinct from Southern Rhodesian white politicians - although there was a small minority of the latter in support of the former in this period. 


\section{Timothy Scarnecchia}

South Africans stood in the way of United States (US), Soviet, and UN goals. One possible outcome of the UN's fighting with Katanga was continued intransigence on the part of Tshombe and the creation of a new political federation including Northern and Southern Rhodesia, South Africa, and Katanga. In the Cold War context of 1960-61, this new coalition of settler states and a new illegal but wealthy pro-Western African 'state' was not out of the question. In the midst of this showdown, it was the death of UN Secretary-General Dag Hammarskjöld on 18 September 1961 that forced Welensky's CAF and the South Africans to back away from a more hardline position on Katanga (O’Brien 1962:4).

Sir Roy Welensky and other Southern African white politicians who supported Tshombe rationalised this support by arguing they were creating a 'buffer' state in Katanga that could protect them from the growing influence of the Soviet Union in Africa. They also believed the British and Americans would support Katanga should the conflict in the Congo come down to a Cold War conflict. In 1960, North Atlantic Treaty Organisation (NATO) member states supported Belgian military defence of Katanga, and Welensky believed that CAF support was in line with Western interests. In early 1960, the CIA was suggesting the need to purchase an estimated ' 1500 tons of uranium-oxide' stockpiled in Katanga as a precautionary measure to prevent it falling into Soviet control (Department of State, U.S. 1992:516). This made the support for UN efforts in Katanga a difficult one for the US and the British in particular, and both were unwilling to fully support the UN's military efforts until they were convinced that the Congolese central government was sufficiently pro-Western. However, as all the pieces began to fall in place for a reunited Congolese government in August 1961, Welensky's continued support of Tshombe stood in the way and became an embarrassment for Western interests. As Namikas argues, Secretary-General Hammarskjöld gambled that the use of force against Katanga would work to galvanise American support for the UN mission. Hammarskjöld's personal role in Katanga negotiations with Tshombe would, however, ultimately lead to his death (Namikas 2002:350). After his death, Hammarskjöld's strategy succeeded with the Americans and the British supplying the necessary military support and transport for the UNOC operations in Katanga to go ahead. 
An interesting source of information about Welensky's and South Africa's role in Katanga is found in the South African archives in a series of reports from the South African High Commissioner in Salisbury to the Minister of External Affairs in Pretoria. The South African High Commissioner, H.K.T. Taswell, became a strong advocate for South African assistance to Katanga - including clandestine military aid through the Federation - and of Welensky's reasoning that such support would ultimately help South Africa and Southern Rhodesia overcome their international isolation brought on by internal political violence in 1960. These official sources offer a unique view of the way the defence of Katanga helped shape white Southern African views of their future role in what they viewed as a common defence against communist and 'Afro-Asiatic' control of Africa through the United Nations.

Before the Katanga secession, South African High Commissioner Taswell had sent glowing reports to the Minister of External Affairs about Welensky's tough language for the British. On 18 March 1960, Taswell reported the 'growing discontent' among white politicians 'with United Kingdom policy in Africa and deep concern at the apparent readiness of the British Government to sacrifice the White people in Southern Africa to black extremism' (Taswell 1960:1). Taswell reported how Welensky continued to attack the Colonial Office, and how Welensky 'strongly resented being referred to as a settler' and claimed that he was a “'White African"'. Taswell then suggests that Welensky's message forced British Prime Minister Harold Macmillan to soften the language used to describe whites in the CAF. Macmillan is reported to have said in a televised interview, 'that the problems in the Federation are totally different and that "Hundreds of thousands of our own people live there. They have their rights too. They brought wealth and civilization to darkest Africa. Can't we approach the whole matter with a little humility, and preferably some knowledge of the facts?"' Taswell suggested, 'Perhaps the winds of change in Africa are beginning to blow in the direction of London, too' (Taswell 1960:2). According to historian Tom Noer, the reports of violence against whites in the Congo did in fact help the political cause of those who claimed independence in sub-Saharan Africa had been 'premature', '.. and gave new credence to the claims of Lisbon, Salisbury, and Pretoria that they were the only safeguards against violence, tribal warfare, and radicalism' (Noer 1985:57; cf. Dunn 2003). 


\section{Timothy Scarnecchia}

In early 1961, following Lumumba's assassination at the hands of Belgian and Katanga forces and with the British signalling that the CAF could be scrapped in order to make way for African rule in Zambia and Malawi, Taswell remained a strong believer in Welensky and made the case that Sir Roy was defending whites in Southern Africa against the growing 'selling out' of white interests by the British, the Americans, and the United Nations. Taswell (1961b:1) wrote disparagingly of the British:

The British Government's policy is strongly in favour of giving much more say to the black man. But whereas United Federal Party policy is essentially a long term go-slow one with no intention of handing over to extremists, the United Kingdom favours a rapid hand-over-now approach. One cannot but detect in United Kingdom policy a feeling of apathy towards the white man in Africa and a strong desire to rid Britain of its overseas colonial responsibilities as quickly as possible.

Events in the Congo continued to fulfil fears among politicians in Southern Africa that they were being abandoned and betrayed for Cold War interests. Following Lumumba's assassination in January 1961, the 21 February UN Security Council Resolution 161, which authorised the use of force in Katanga as a pre-emptive measure to prevent a civil war in the Congo, increased the sense that the Americans, British, and the UN were now willing to sacrifice the interests of whites in Southern Africa. This resolution confirmed the feeling among Rhodesian politicians that they were under siege from the international community - particularly Western forces that had previously been seen as their natural allies.

Taswell's letters also confirm that the CAF was supplying weapons and armoured steel to Tshombe's forces. This was assumed by the British and the Americans, but apparently only confirmed by the British and communicated to the Americans by December 1961 (Hughes 2003:607; Kent 2010:79). Taswell reports that he had learned that 'the Federal Government takes the view that Tshombe is fighting their battle for them and they have asked him to state what he wants from them in the way of military and other equipment'. Taswell requested that South Africa take seriously Tshombe's requests, as such supplies could be shipped as mining 
equipment and get past the UN troops with the CAF's help. Taswell (1961a:3) made an appeal for South African aid using the following Cold War and race war logic:

If Tshombe fails, the drive to the south will be on. The Rhodesias, already in a shaky position, may collapse and we will be the main target. Whether or not we have been strictly correct in our supply of material to Tshombe will be of little consequence.

Taswell once again praised Welensky's efforts to help Tshombe defy the UN, the Americans, and the Afro-Asian nations.

Welensky apparently briefed Taswell on 12 October 1961 about his efforts to support Tshombe during the UN military operations. Welensky had summoned Tshombe to Salisbury to give him advice on how best to respond diplomatically after the UN's use of force. Taswell describes Welensky's account of his meeting with Tshombe: 'While he does not always think too much of the black man as a statesman, Sir Roy said, he was greatly impressed with Tshombe's ability and sincerity'. Welensky apparently told Tshombe that he couldn't take on the whole Afro-Asian block on his own, particularly with India's Nehru so committed to defeating Katanga. Welensky told Tshombe, '[t] he Katanga was the first setback the Afro-Asian bloc had suffered in Africa and it was therefore essential that he, Tshombe, should do all he could to capitalise on it. He must play his cards extremely well' (Taswell 1961c:2). Most of Welensky's advice was in fact followed by Tshombe - to move extremely slowly in negotiations with Congolese Prime Minister Cyrille Adoula in order to buy time to regroup militarily and then to bring Katanga back into the Republic only on terms that would allow Tshombe to survive politically.

Welensky also told Taswell that he was responsible for ending the UN's military campaign. Sir Roy claims to have 'delivered an ultimatum' that 'unless the United Kingdom took steps at once to check the United Nations he was ordering the RRAF [Royal Rhodesian Air Force] into action'. Claiming that his ultimatum worked, Welensky told Taswell, 'While Tshombe and I could not have taken on the world we could have cleared up the U.N. bunch in no time. And that, "he smiled" would really have started something' (Taswell1961c:2). Welensky's 


\section{Timothy Scarnecchia}

threats to use additional force were real. Dayal indicates that Lord Landsdowner, the British Under-Secretary of State, remarked in the British Parliament after returning from the Congo that he (Welensky) had threatened UN SecretaryGeneral Hammarskjöld, insisting that he stop the fighting immediately, and that ' $[\mathrm{t}]$ here was also an implication that Tshombe would be supported militarily from Northern Rhodesia and the United Nations would get bogged down in a war of attrition which would effectively destroy the Organization' (Dayal 1976:273). While such tough talk made Welensky popular with the South Africans, it hardly endeared him with the British and Americans. The British military went as far as planning a possible military action against the Rhodesian Royal Air Force because of Welensky's intransigence over Katanga and the Federation (Murphy 2006).

Reacting to UNOC's Operation Mothar, Federation politicians spoke out in the Federal Parliament. Included in the more sensational responses was the then future Rhodesian Front Prime Minister, Winston Field, who '... accused the British Government for a vacillating policy "at the behest of their American masters." He urged that a firm stand should be taken in support of Mr Tshombe whom he described as "a friend" (Central African Daily News 1961c). John Gaunt, who then represented Lusaka in the Federal Parliament but who would later plot against Winston Field to bring Ian Smith to power in the Rhodesian Front, argued for a state of emergency to be declared in the Federation. Gaunt said in Parliament, "'Legalities can be fixed later.... We have no time; we must act now," he urged. Describing events in Katanga as "organised pillage", he said the United Nations - an organization set up for peace - had now become a band of mercenaries. "We must resist them"' (Central African Daily News 1961c).

\section{The impact of the UN and the Congo crisis on Zimbabwean African nationalism}

As events in 1961 unfolded, including the assassination of Congolese Prime Minister Patrice Lumumba by the Belgian and Katanga forces in February 1961, it became increasingly clear that the Congo presented opportunities for

Zimbabwean nationalists to position themselves for financial and military support from Cold War interests. Both the Soviets and the Americans attempted 
to influence the Zimbabwean nationalist movement, and in the early 1960s this primarily meant providing financial assistance to the nationalists and trade unions. The Congo crisis provided some leverage for Zimbabwean nationalists to make their case for Cold War support. Vladimir Shubin, in his history of the Soviets in Southern Africa, describes how the Zimbabwean National Democratic Party (NDP) received financial assistance in 1960 from the Soviets, not only because they were seen as “ “... the most progressive and mass party"', but also because George Silundika, the NDP's representative, had convinced the Soviets that the NDP “ “... is conducting certain work in the province of Katanga against the government of Tshombe in defense of the lawful Congolese government of P. Lumumba"' (Shubin 2008:152). American sources were also providing funds to anti-communist trade unionists, and then in 1961 directly to the nationalists, in hopes of keeping the nationalists from Soviet influence.

On 11 October 1960, Zimbabwean leader Joshua Nkomo made an appeal at the UN for Security Council intervention three months after the Congo crisis had begun and two months after rioting and protests in Southern Rhodesia in 1960. These riots in Salisbury, Bulawayo, and Gwelo were the first time since the late 19th century that Rhodesian police had opened fire on Africans, and Nkomo's speech attempted to indicate the growing sense that the State was now using deadly force as had happened in South Africa, South West Africa, and the Portuguese colonies in 1960. Nkomo's goal was to push the United Nations to force the British to intervene:

... There will be no peace in Southern Rhodesia unless the British Government intervenes at this stage and accedes to African demands of a constitutional conference failing which the Africans shall press forth for an immediate suspension of the constitution of the country, so as to give time for the drafting of a constitution that will give power to the people and not to a minority section (Nkomo 1960). ${ }^{2}$

2 Andrew DeRoche has written extensively on the US relations with Central Africa during the Cold War. DeRoche highlighted the warning of the US Consul-General in Salisbury, which echoes Nkomo's concerns. Following the July 1960 riots in Bulawayo and Salisbury and the Sharpeville massacre in April 1960 in South Africa, 'Palmer believed that only fundamental political reform instigated by Great Britain combined with significant financial aid from the United States could guarantee stability in the region. Otherwise, the Federation could conceivably descend into chaos resembling that in the Congo' (DeRoche 2001:36). 


\section{Timothy Scarnecchia}

If the UN did not intervene, he predicted the beginning of a race war and claimed that the UN needed to act quickly, or else '.. the U.N. will have failed millions of dependent people who are looking up to it for their hope for the security and peace for which they gave their lives in the last two wars'. He ended his statement by pointing out, '... white settlers in Central Africa and in Southern Rhodesia in particular are arming themselves against the African people, and they have gone as far as recruiting white South Africans to assist them in their pending war against Africans. When placed in the context of the Congo crisis and the UN's very ambitious commitment to bringing it to an end, Nkomo's strategy was part of a diplomatic effort to compare the 'chaos' in Southern Rhodesia as similar to the rationale used to secure UN intervention in the Congo.

Joshua Nkomo's 1960 attempt to direct the UN Security Council's attention to the State-sponsored violence in Southern Rhodesia failed to elicit Security Council action. All subsequent appeals would have the same result. While numerous General Assembly resolutions were passed to try and push the British to take responsibility for the situation in Rhodesia, these were symbolic with little real force behind them. The relative weight of the Southern Rhodesian crisis, in Cold War terms, was far less than that of the Congo crisis. It can be argued, however, that the Congo crisis and the divisiveness of Tshombe's Katanga, would offer an important framework upon which the Zimbabwean nationalists constructed their strategies in these years.

The strongest criticisms of the UN and the US came after 13 February 1961 as the official news of Patrice Lumumba's assassination reached Salisbury. The American Consul-General, John K. Emmerson, who had served in Japan during World War II and been an American emissary to the Chinese Communist Party in 1946, expressed concern over the 'venom being directed against the US' from even Herbert Chitepo, who he described as a 'pro US-Southern Rhodesian lawyer'. Chitepo and others were blaming the US 'for failure [to] support Lumumba and for UN failure in the Congo'. The most vocal criticism of the UN and US came from George Silundika, the NDP's Cairo representative, who Emmerson describes as having 'saturated' himself with the Communist line. In Emmerson's opinion, the 'African nationalist movement here could now take on new red-hued complexion' (Emmerson 1961a). Josiah Chinamano, an important nationalist 
leader who was employed at the time by the US Consul-General, reported an interview with Silundika on 17 February, in which Silundika '... claimed that the Americans are "very cunning"; in other parts of Africa, particularly in the Congo, they have "bought" a number of African leaders and the NDP would have to be very careful to see that none of its officials were so bought'. Chinamano concluded that Silundika had been 'deeply contaminated during his stay in Cairo and his visit behind the Iron Curtain'. Chinamano noted, on what was to be his last day working for the Americans, that Silundika's anti-American argument marked '... the stage where we can identify for the first time the forerunner of the Soviet effort to penetrate the nationalist movement in the Colony. Things will never be the same' (Emmerson 1961b). The Lumumba assassination helped to galvanise a nationalist identity in Central Africa based on an anti-imperialist message. While many of the Zimbabwean nationalists continued to work closely with the Americans, and in fact would receive financial support from the Americans to build up their opposition to minority rule, they could not help but take advantage of the organising opportunity offered by Lumumba's assassination. Here was a Cold War intervention that showed the price nationalists would pay should they go against Western interests. Silundika and Enos Nkala organised seven NDP meetings in all the major urban areas in Southern Rhodesia to attack the US for Lumumba's death. Nkala even went as far as to reportedly say at the rallies that when the NDP gains power, the Consul-General and his staff would be 'sent packing' (Mulcahy 1961). The stage was therefore set to attack Zimbabwean nationalists with open ties to American funding.

Six months later, Zimbabwean nationalists' reactions to the UN's active military role in Katanga beginning in August 1961were more cautious than their response had been to Lumumba's assassination. Stanlake Samkange noted that if it were true that Welensky and the Federal government were providing assistance to Katanga, such actions would legitimatise the intervention of the Congo government in affairs of the Federation, leading to a potential border war (Samkange 1961). George Silundika reportedly sent a cable to the UNIP leadership the day after Operation Mothar began, 'urging them to see that the N. Rhodesia-Katanga border is searched for any fugitives, including Mr Tshombe and Mr Munongo ...' and to '... see that that no Katanga political refugee is allowed into Northern 


\section{Timothy Scarnecchia}

Rhodesia' (Central African Daily News 1961c). The African press was also cautious in their response to UNOC military actions in Katanga since they could not condone intervention to put down a secession, as it was well known that Dr Hastings Banda, the nationalist leader in Nyasaland, was threatening to secede from the CAF.

There were stronger public criticisms following the death of UN SecretaryGeneral Dag Hammarskjöld on 18 September 1961 as part of his personal diplomacy to end the Katanga secession. A joint statement issued by Joshua Nkomo and Kenneth Kaunda, the 'Zambezi Declaration' of 22 September 1961, called for majority rule in both Northern and Southern Rhodesia. Coming four days following Hammarskjöld's death, the Zambezi Declaration commented on the incident, as the Central African Daily News (1961d:1) reports:

The joint statement blames the death of Mr Dag Hammarsjoeld [sic] on international intrigue and conspiracy which also led to the death of Mr Patrice Lumumba. It views with grave concern the interference in the internal affairs of the Congo by the British Government, the imposed Federal Government, and the Verwoerd Government. 'In S. Rhodesia African people have been killed for calling for majority rule; in N. Rhodesia some are dying now; and thousands of our followers languish in detention camps and prisons. Yet', it charges, 'these perpetrators of political crime against humanity are arming Tshombe to the tooth to fight his way out of the Congo Republic not because they like Tshombe, but because they want to extend the hold of colonialism and imperialism?

By October 1961, the UN's campaign against foreign mercenaries in Katanga drew stark lines among regional leaders. On the one hand, Welensky continued to publicly deny any involvement. The American Consulate-General's office telegrammed to Washington Welensky's 10 October press conference where Welensky claimed the 'GNR [Government of Northern Rhodesia] has always maintained strictest neutrality RE use [of] force in Congo and taken "considerable pains" [to] prevent arms and military equipment [from] crossing border. GNR also has refused [to] let such traffic pass through its territory' (Emmerson 
1961c). ${ }^{3}$ On the other hand, the hatred of Tshombe helped to forge closer ties between Nkomo, Kaunda, and Dr Hastings Banda in Nyasaland. For Central African nationalists, therefore, the key events and personalities of the Congo began to take a life of their own as they hoped to bring international attention to the real crisis in the Rhodesias, not just in the Congo. The combination of international lobbying and internal factionalism led Zimbabwean nationalists to adopt the language, and even the logic, of the Congo crisis for their own struggle.

The primary form of this was the use of Tshombe as the archetype of the 'sellout' politician, while the martyred Lumumba became the archetype of the pure panAfricanist. The increasingly oppressive Rhodesian state during the early 1960s, particularly given the voting into power by a minority electorate of the extremist Rhodesian Front in 1962, meant that hopes of negotiated majority rule decreased over time. Faced with white political intransigence and repression, the nationalist movement turned to creating popular opposition to the Rhodesian state through general strikes and acts of violence and sabotage. In 1961, when Joshua Nkomo was told by the British that Southern Rhodesia's industry and economy were too important to turn over to Africans, Nkomo vowed to 'destroy' Southern Rhodesia's industry and make the country ungovernable. The Rhodesian state responded with more arrests and detentions and the banning of the NDP.

By May of 1962, Nkomo and others in the Zimbabwe African People's Union (ZAPU) - which had been formed in December 1961 to replace the banned NDP - were calling for a general strike to create 'chaos' in Southern Rhodesia. Part of the motivation for this general strike was to help put Southern Rhodesia on the agenda of the UN General Assembly's special session in June (Geren 1962). The strike was largely a failure, resulting in the arrests of more nationalists and for

3 Welensky's capacity to maintain a lie continued with his 25 October statement where he described the allegations from the UN that he was supplying Tshombe's troops with materials as 'irresponsible hysteria. Welensky stated, "Let me say again in simplest terms that the Federal government has not supplied military equipment or mercenaries to the Katanga forces". He concluded, "I recognize, however, that denials by me will have little effect on such people and that baseless and quite unsubstantiated rumours about Federal actions will continue to be quoted as the truth by those who subscribe only too obviously to the Nazi doctrine that the truth does not matter in world affairs; what counts is only what lies you can get away with"' (Emmerson 1961d). 


\section{Timothy Scarnecchia}

the first time, the firing of thousands of African workers who participated in the strike. The use of general strikes to gain the attention of the United Nations in 1962 was one part of a larger divide in the nationalist movement, one that had to do with the continued independence of the African trade union movement from ZAPU control.

The main target of the NDP and then ZAPU was the leader of the Southern Rhodesian Trade Union Congress (SRTUC), Rueben Jamela. Jamela had previously risen to the leadership role of the SRTUC after Joshua Nkomo and others had taken leadership roles in the nationalist movement. Jamela had helped form the nationalist movement and saw himself as a nationalist, but he defended the independence of the SRTUC from the nationalists because he believed if they were to fall under one leadership, the Rhodesian state would ban the SRTUC. With 30000 members, the SRTUC would be unable to continue working for African workers and the nationalist movement. Throughout 1961 and 1962, George Silundika and Robert Mugabe were the most vocal critics of Jamela's American and European funding. Making matters worse, Jamela jealously guarded his financial ties to American and European trade union funding (Scarnecchia 2008:111-116).

As Jamela refused to relinquish control of the SRTUC to ZAPU, a rival African trade union was formed by ZAPU to pull members and international funding away from Jamela. This new African Trade Union Congress (ATUC) attacked Jamela in the main rhetorical form available, as a sellout. The ATUC's 'Personal Letter to Jamela', published in the Workers Voice of March 1962, indicates how much of the then recent events in the Congo shaped the political language within the Zimbabwean nationalist movement. The letter first compared Jamela to the failed Northern Rhodesian nationalist Harry Nkumbula who had accepted funding and vehicles from Tshombe (see Macola 2010:86). The letter warned Jamela, 'Your sell-outism is known by all the workers it does not matter how many cars you may buy'. The letter then commented on a speech Jamela had made to workers and responded to the possibility that Jamela would start a competing African political party. 
You said to them according to what you understand that political freedom in Zimbabwe cannot be won by politicians but by trade unionists when you gave an example of the Congo where Lumumba the son of African [sic], you said failed and that because Adoula who is former trade unionist has got the reigns of Government the Congo not going to fail, in any way? Do you think you the Adoula? We can assure you that you will never put your foot in parliament on the ticket of the workers the African but on the ticket of your own political bosses...Why don't you come to your senses and realise things. We won't support a sell out of your type (Workers Voice 1962:7).

The ATUC was less successful in organising the May 1962 General strike, and this helped Jamela regroup. Soon after, however, as the war of words and the sellout accusations turned into deadly battles between his supporters and ZAPU, Jamela fell out of favour with his American and European supporters. Geren notes that by early 1963 Jamela's 'standing among Africans' was regarded 'as having fallen to a level only slightly higher than that of Tshombe' (Geren 1963a). The ZAPU leadership succeeded in weakening Jamela's power over both a large rank and file membership and international funding. In 1963, however, this process would be repeated within ZAPU itself as a leadership split led to the breakaway formation of the Zimbabwe African National Union (ZANU) by August 1963.

The ZANU-ZAPU split also demonstrated the use of Congo-related rhetoric as both parties claimed to be the true pan-Africanist organisation in the tradition of Lumumba, while portraying the other party as Tshombe's - those who would sell out Zimbabwe to the highest bidder. Again, both ZAPU and ZANU were receiving financial support from numerous sources, ZAPU from the Soviets and the Americans, and ZANU from the Chinese and the Americans. Joshua Nkomo and those who remained with ZAPU immediately charged that ZANU was an American-inspired splinter group created with assistance of the US Ambassador in Tanzania, William Leonhart. ZAPU leaders such as Nkomo, Reverend Ndabaningi Sithole, Herbert Chitepo and others had been to Washington DC and New York City to raise funds for ZAPU from American mining companies while also petitioning at the United Nations. After August 1963, Reverend Sithole, 


\section{Timothy Scarnecchia}

Chitepo, and Robert Mugabe were leading ZANU and Nkomo carried on as leader of ZAPU, and both parties continued to request and receive American funding, mostly in the form of direct contributions from mining companies. Nkomo expressed his concerns that Sithole and ZANU would use American funding to 'sellout' the country's resources, and invoked afresh the memory of Lumumba's death in a speech he gave at Fort Victoria a month after the ZAPU-ZANU split. A newspaper account records that

Nkomo said the United States will 'help us get the whites out' but with the aim afterwards of exploiting the country's mineral resources. Nkomo said that while he was in New York a few months ago he had visited the offices of an American mining company engaged in operations in Rhodesia. Nkomo said, 'The minerals are here, but so is the cheap labor...Patrice Lumumba died because he refused to sell the Congo to America...' Nkomo added, 'It does not matter about Sithole or Nkomo; but who is going to get our country back and not sell it to someone else.' He asked the crowd if they wanted money from Britain, America or Russia, to which the crowd roared: 'No' (Geren1963c). 4

The American Consul-General, Paul Geren, asked ZAPU's publicity secretary, Willie Musururwa, whether or not this was what Nkomo had said. Musururwa claimed it had been taken out of context but, added that 'Fort Victoria has been the scene of the Sithole group's [ZANU's] greatest success to date, and it thus was not surprising that Nkomo would pull out the stops on the United States, to whom he has branded Sithole a "sellout". The Americans tried their best to give support to both ZAPU and ZANU after the split, but it proved increasingly difficult to justify in light of the anti-American rhetoric both sides used to gain support - given the Tshombe-Lumumba rhetoric already in place before the split.

In September 1963, American Consul-General Paul Geren asked ZANU leader Ndabaningi Sithole to comment on an anti-American statement made in China

4 Ellipses in original. 
by ZANU's representative Tranos Makombe. ${ }^{5}$ Sithole responded by saying it was difficult for him and others in ZANU, who the US viewed as 'safe' given their pro-American views, to receive as much funding from the Americans compared to those who were more likely to be supported by the Soviets (in this context, ZAPU). Sithole told Geren that 'Officers in the Department of State talk big and with encouragement but when it comes to acting to help a cause like Sithole's they cannot deliver'. Sithole also criticised the US for choosing to abstain at the $\mathrm{UN}$ on votes that were designed to force the British to take more responsibility for bringing majority rule to Rhodesia. Sithole remarked,

Africans observe that the Soviet Union supported Southern Rhodesia's case at the Security Council and in the General Assembly while the United States merely abstains. The African public concludes from this that the United States does not in fact support the Southern Rhodesian nationalists while the Soviets and the communists do support them (Geren 1963d).

An American diplomat at the meeting told Sithole '.. that threats of communist blackmail are not a successful method for winning American friends nor assistance from the United States government'. Geren then explained that the US abstentions at the Security Council did not mean the US was 'against Southern Rhodesian nationalists rather it meant that we saw no good purpose to be served by the resolution. ... our action must be of a kind calculated to encourage the most helpful response from the UK' (Geren 1963d).

American Consul-General Geren was closer to Robert Mugabe than to Sithole. Geren had travelled to Dar es Salaam to meet with Mugabe a few days after Sithole and Mugabe formerly launched ZANU. Geren noted that Mugabe's views of the usefulness of the United Nations had changed after the split, given that Nkomo

5 Makombe reportedly had said on Chinese radio: "'To all oppressed people, the Chinese revolution offers the best example of how to struggle against imperialism and colonialism and for national liberation...An example of this is the recent statement by Chairman Mao Tse-tung condemning racial discrimination against Negroes in America. The Chinese people are also firmly opposed to imperialism and modern revisionism"' (Geren 1963d). Ellipse in original. 


\section{Timothy Scarnecchia}

and George Silundika had made very good use of the UN for ZAPU's recognition, and ZANU had yet to be recognised there. Geren observed:

Mugabe considers there is little point in additional UN resolutions on Southern Rhodesia. So far as the Security Council is concerned, Mugabe said: 'Southern Rhodesia is not a threat to world peace. In fact there is no threat to the internal security of Southern Rhodesia' (Geren1963b).

Mugabe's attitude toward the UN apparently changed a few months later after having had the opportunity to go to New York City. Returning to Dar es Salaam in November 1963, Mugabe told US Ambassador William Leonhart that ZANU needed assistance in financing a permanent representative in New York, which Mugabe called the "“single most important location in the world"'. It was Tanzanian politician Oscar Kambona who organised and accompanied Mugabe on his first trip to the UN in order to counter ZAPU's representative, George Silundika (Leonhart 1963).

Even though Mugabe was excited about having a ZANU representative at the $\mathrm{UN}$, he remained cautious about the potential influence the UN could have on Southern Rhodesia. Mugabe told Leonhart that little was likely to come from the UN or the Secretary-General's 'good offices'. Mugabe thought that both the British Government and the Rhodesian Front Government were 'too mistrustful of UN initiatives in Africa and would not wish [to] see [the] UN receive any credit for S[outhern]R[hodesia] progress' (Leonhart 1963). Despite the efforts of Ghana's Kwame Nkrumah to force a Security Council Resolution requiring the British to block the turning over of the CAF's military to Southern Rhodesia in 1963, the UN failed to push Britain to take more immediate action on the Rhodesian crisis (Hubbard 2011:348). If anything, the series of General Assembly resolutions passed to pressure Britain to take a stronger stance on Rhodesia majority rule helped to galvanise white minority rule and justify stronger measures against the nationalists. As Frank Clements observed, resolutions such as Resolution 1760 (XVII) (31 October 1962) calling for the British to suspend the Southern Rhodesian constitution and immediately grant majority rule, helped to build up resistance to outside pressures within white politics. 'Britain would find that 
they [Rhodesians] could be just as threatening and just as defiant as any black nationalists' (Clements 1969:187). In this sense, the Katanga experience had shown how a small minority with control over the police and military could survive the onslaught of UN opinion. This lesson was not lost on either side of the Rhodesian conflict.

\section{Conclusion}

The Congo crisis helped to shape the rhetoric and intransigence of African nationalism in Southern Rhodesia. It also helped shape the relationships of African nationalists toward Cold War and mining interests in the region. The historical contingency of having such a major Cold War conflict occurring at the same time as the Zimbabwean nationalists struggled with Rhodesian state repression meant that Zimbabwean nationalists could turn to American, Soviet, and Chinese financial assistance. Not one of these powers, however, viewed Southern Rhodesia as strategically important relative to the ongoing Congo conflict. The role of Federation Prime Minister Sir Roy Welensky in publicly supporting Moise Tshombe in the Katanga hurt the reputation of the Federation but this was countered by the perception in the United States and elsewhere that the violence in the Congo originated in African 'chaos' and not from the myriad external interests competing over the Congo's strategic resources. Equally important, the continued Anglo-American alliance guaranteed that the United States was not going to vote against the UK at the UN over Rhodesia (Hubbard 2011).

The largest impact of the Congo conflict, particularly the Western power's role in the assassination of Patrice Lumumba and support for Mobutu and Tshombe, was on internal Zimbabwean nationalist competition. The deployment of 'sellout' politics, which at one level paralleled white political views of Western interests in the region, worked to give a rhetorical edge to those who could make greater claims to an authentic pan-African position. The debate over pan-African authenticity made more sense when fashioned as a choice between the 'Tshombes' and the 'Lumumbas' in the struggle. In shaping this debate, the contradictions of nationalists and trade unionists seeking funding from all sides of the Cold War were more or less resolved through a violent code of conformity. What couldn't 


\section{Timothy Scarnecchia}

be debated at the level of ideology or strategy was decided through factional violence. There is some indication that in the early years, at least, Nkomo and others hoped to mobilise strikes and riots to gain the attention of the United Nations in hopes that the Security Council would intervene. When the prospects for intervention seemed less likely, the United Nations became viewed more as an important site of legitimation for different nationalists rather than as an institution that was likely to intervene on the behalf of the nationalists.

What then was the legacy of the UN's intervention in the Congo in 1960-61 for Southern Rhodesia and the Zimbabwean nationalists? Most importantly, Sir Roy Welensky's over-confident view that the CAF could, with South Africa's assistance, defend Katanga against the Congolese government and the United Nations signalled the end of confidence in CAF politicians to dictate regional politics. There were too many contradictions in the overlapping of racial and Cold War politics. However, the common belief in South Africa and Southern Rhodesia that the UN's intervention was part of an American attack on whites in Southern Africa persisted. Therefore it can be argued that the Congo crisis helped to push Southern Rhodesia and South Africa closer together, as expressed in Taswell's often hyperbolic praise of Welensky's Katanga strategy.

While the Congo crisis helped to further divide racial politics in Southern Rhodesia, contemporary readings of Dag Hammarskjöld's death were not necessarily divided along racial lines. African leaders and newspaper editors viewed his death as a tragic loss and blamed Welensky for creating the political situation leading to his death. But a popular feeling persisted, and was encouraged by the messages from nationalist leaders, that the Secretary-General and the UN were doing the bidding of the Americans and Western nations, which continued to insinuate blame on the UN for Patrice Lumumba's death. As an example, on 7 October 1961 - the day before a major riot in Salisbury - the African press reported on a NDP rally in Bulawayo where 'One of the speakers, Mr K. Ncube was booed when he called for a minute silence for the late Secretary-General of the United Nations' (Central African Daily News 1961e). The rhetorical logic of Zimbabwean nationalism, to the extent that it was increasingly defined in relation to imperialism, did 
not allow Hammarskjöld's contribution to be understood outside of the racial imperialism trope that dominated the conflict in Southern Rhodesia.

The NDP's publication Radar had promoted this 'common sense' view in December of 1960, a month before Lumumba's assassination:

When Africans invited the United Nations to come to the rescue of a Belgian-betrayed Congo, they never intended to introduce cold war politics into Africa. Africans have learnt now the folly of entrusting the freedom of a country to an organisation that is controlled by one big imperialistic country.... Conflicting interests plus the unwillingness of the Western Block to follow out policies that will free the Congo have been responsible for the deadlock at the United Nations. In Africa all trouble comes from conspired and planned subversion of African States by one or other of the Western Alliance (Radar 1960:8).

While nationalist leaders expressed their condolences for Hammarskjöld and blamed his death on Welensky and others who supported Tshombe with weapons and mercenaries, it was not clear at the time of Hammarskjöld's death that Tshombe and Katanga had in fact been completely defeated. If Tshombe, with Welensky's assistance, could renegotiate his role in the central government, the Katanga lobby would have succeeded in their goal of keeping the mining interests of Katanga, Northern Rhodesia, and Southern Rhodesia under their continued control. The lesson from the Katanga conflict for Zimbabwean nationalists was to keep future Tshombes from coming to power. It was better to deal with them beforehand. This would be the strategy Mugabe and ZANU would use moving forward, and after 10 years in prison and detention, this helps to explain Robert Mugabe's and ZANU's advantage over other Zimbabwean nationalists starting in the mid-1970s. This Cold War lesson seriously limited the room for political moderation in nationalist circles, leaving a destructive legacy in post-independence Zimbabwe. The other lesson learnt from the Congo crisis, and Zimbabwean nationalists' unsuccessful appeals to the UN Security Council for intervention, was that a fighting force - 


\section{Timothy Scarnecchia}

even a small one with 300 odd white mercenaries and one fighter plane as in the case of Katanga - was an absolute necessity in order to be taken seriously by Cold War interests and, not insignificantly, by the United Nations.

\section{Sources}

Central African Daily News 1961a. The Katanga fiasco. Central African Daily News, 14 September, p. 1.

Central African Daily News 1961b. Federal House disgusted by UNO intervention in Katanga. Central African Daily News, 14 September, p. 1.

Central African Daily News 1961c. NDP to cable UNIP. Central African Daily News, 14 September, p. 1 .

Central African Daily News 1961d. Nkomo, Kaunda, repeat call for majority rule in the two Rhodesias. Central African Daily News, 23 September, p. 1.

Central African Daily News 1961e. Political holiday over: NDP and ZNP go into action. Central African Daily News, 7 October, p. 3.

Central African Daily News 1961f. Tshombe was in city. Central African Daily News, 11 October, p. 1.

Clements, Frank 1969. Rhodesia: A study of the deterioration of a white society. New York, Praeger.

Cordier, Andrew W. and Wilder Foote 1975. Public papers of the Secretaries-General of the United Nations. Vol. 5. Dag Hammarskjöld, 1960-1961. New York, Columbia University Press.

Dayal, Rajeshwar 1976. Mission for Hammarskjöld: the Congo crisis. London, Oxford University Press.

Department of State, U.S. 1992. Foreign relations of the United States. Africa, 1958-1960 Vol.14. Washington, D.C., Department of State.

DeRoche, Andrew 2001. Black, white, and chrome: The United States and Zimbabwe, 1953-1998. Trenton, NJ, Africa World Press.

De Witte, Ludo 2002. The assassination of Patrice Lumumba. London, Verso.

Dunn, Kevin 2003. Imagining the Congo: The international relations of identity. London, Routledge.

Emmerson, John K. 1961a. American Consul-General to State, 745c.00/1-361 February 20. Pol 12 Rhodesia and Nyasaland. RG 59, United States National Archives II, Washington, D.C.

Emmerson, John K. 1961b. American Consul-General to State, 745c.00/2-2361 February 23, Pol 12 Rhodesia and Nyasaland. RG 59, United States National Archives II, Washington, D.C.

Emmerson, John K. 1961c. American Consul-General to State, telegram No. 284. October 10. Pol 12 Rhodesia and Nyasaland. RG 59, United States National Archives II, Washington, D.C. 
Emmerson, John K. 1961d. American Consul-General to State, telegram No. 334. October 26. Pol 12 Rhodesia and Nyasaland. RG 59, United States National Archives II, Washington, D.C.

Geren, Paul 1962. American Consul-General Salisbury to State. Background on Salisbury General Strike. May 14.RG 59 845C.062/5.1762, United States National Archives II, Washington, D.C.

Geren, Paul 1963a. American Consul-General to State. Third Annual Labor Report. February 13. Pol 12 Rhodesia and Nyasaland. RG 59, United States National Archives II, Washington, D.C.

Geren, Paul 1963b. American Consul-General to State. Conversation with Robert Mugabe, Secretary-General of ZANU, Dar-es-Salaam, August 12. Pol 12 Rhodesia and Nyasaland RG 59, United States National Archives II, Washington, D.C.

Geren, Paul 1963c. American Consul-General to Department of State. Nkomo Questions U.S. Motives to 2,000 at Fort Victoria. September 10. A-263 September 10, 1963. Pol Rhodesia and Nyasaland. RG 59, United States National Archives II, Washington, D.C.

Geren, Paul 1963d. American Consul-General Salisbury to State. September 26. A-317 Pol 12 Rhodesia and Nyasaland RG 59, United States National Archives II, Washington, D.C.

Govender, Robert 1971. The martyrdom of Patrice Lumumba. London, Neillgo.

Hubbard, James P. 2011. The United States and the end of British colonial rule in Africa, 1941-1968. Jefferson, NC, McFarland.

Hughes, Mathew 2003. Fighting for white rule in Africa: The Central African Federation, Katanga, and the Congo Crisis, 1958-1965. International History Review, 25 (3), pp. 596-615.

Kent, John 2010. America, the UN and decolonisation: Cold War conflict in the Congo. London, Routledge.

Leonhart, William 1963. Dar-es-Salaam to Sec of State. Telegram 5856, November 8. Pol 12 Rhodesia and Nyasaland. RG 59, United States National Archives II, Washington, D.C.

Macola, Giacomo 2010. Liberal nationalism in Central Africa: A biography of Harry Mwaanga Nkumbula. New York, NY, Palgrave.

Mazov, Sergey 2010. A distant front in the Cold War: The USSR in West Africa and the Congo, 1965-1964. Washington, D.C., Woodrow Wilson Center Press.

Mulcahy, Edward 1961. Salisbury to Secretary of State, telegram No. 418. February 21. Pol 12 Rhodesia and Nyasaland RG 59, United States National Archives II, Washington, D.C.

Murphy, Philip 2006. An intricate and distasteful subject: British planning for use of force against the European settlers of Central Africa, 1952-65. English Historical Review, CXII (492), pp. 746-777.

Namikas, Lise A. 2002. Battleground Africa: the Cold War and the Congo Crisis, 1960-1965. Ph.D. thesis, University of Southern California. 


\section{Timothy Scarnecchia}

Nkomo, Joshua 1960. Disturbances in Southern Rhodesia. New York, October 11, 1960. RG-18-001 Rhodesia, Box 12 File 4, George Meany Memorial Archives, College Park, MD.

Noer, Tom 1985. Cold War and black liberation: The United States and white rule in Africa, 1948-1968. Columbia, MO, University of Missouri Press.

O’Brien, Conor Cruise 1962. To Katanga and back: A UN case history. New York, Grosset \& Dunlap.

Radar 1960. Into 1961. Radar, 9, 24 December.

Samkange, S.J.T. 1961. Katanga troubles could bring enormous problems to the Federation. Central African Daily News, 15 September.

Scarnecchia, Timothy 2008. The urban roots of democracy and political violence in Zimbabwe: Harare and Highfield, 1940-1964. Rochester, NY, University of Rochester Press.

Shubin, Vladimir 2008. The hot Cold War: The USSR in Southern Africa. London, Pluto Press.

Stapleton, Tim 2009. Bad boys: Infiltration and sedition in the African military units of the Central African Federation (Malawi, Zambia and Zimbabwe) 1953-63. Journal of Military History, 73 (4), pp. 1167-1193.

Taswell, H.K.T. 1960. High Commissioner Salisbury to Secretary for External Affairs. Southern Rhodesia's Future. 18 March 1960. BTS USA Department of External Affairs. Countries, Southern Rhodesia: Relations with South Africa, 5.7.1950 to March 3, 1961. T./S./81 vol. 1 1/156/3, South African National Archives, Pretoria.

Taswell, H.K.T. 1961a. High Commissioner to Secretary for External Affairs, Cape Town. Salisbury, 27 January, 1961. Congo, T./S./81 vol. 1 Southern Rhodesia, South African National Archives, Pretoria.

Taswell, H.K.T. 1961b. High Commissioner Salisbury to Secretary for External Affairs, Cape Town. Salisbury, 6 February, 1961. Constitutional Reviews, T./S./81 vol. 1 Southern Rhodesia, South African National Archives, Pretoria.

Taswell, H.K.T. 1961c. High Commissioner to Secretary for External Affairs, Cape Town. Salisbury, 12 October, 1961. The Federation and the Katanga, T./S./81 vol. 1 Southern Rhodesia, South African National Archives, Pretoria.

Welensky, Sir Roy 1965. Welensky's 4000 days: The life and death of the Federation of Rhodesia and Nyasaland. New York, Roy Publishers.

Workers Voice 1962. A personal letter to Jamela, 1:1. Workers Voice, 16 March, p. 7. 